\title{
Academic impact and perceived value of Wikipedia as a primary learning resource in higher education
}

\author{
Antoni Meseguer-Artola; Inma Rodríguez-Ardura; Gisela Ammetller; Eva Rimbau- \\ Gilabert
}

How to cite this article:

Meseguer-Artola, Antoni; Rodríguez-Ardura, Inma; Ammetller, Gisela; Rimbau-Gilabert, Eva (2020). “Academic impact and perceived value of Wikipedia as a primary learning resource in higher education". Profesional de la información, v. 29, n. 3, e290329.

https://doi.org/10.3145/epi.2020.may.29

Manuscript received on October $1^{\text {st }} 2019$ Accepted on December $28^{\text {th }} 2019$

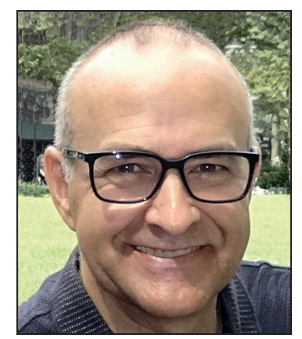

Antoni Meseguer-Artola $\bowtie$ https://orcid.org/0000-0002-7817-3695

Universitat Oberta de Catalunya Facultad de Economía y Empresa Av. Tibidabo, 39-43. 08035 Barcelona, Spain ameseguer@uoc.edu

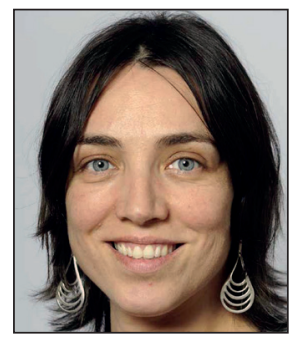

Gisela Ammetller https://orcid.org/0000-0003-3667-1650

Universitat Oberta de Catalunya Facultad de Economía y Empresa Av. Tibidabo, 39-43. 08035 Barcelona, Spain gammetller@uoc.edu

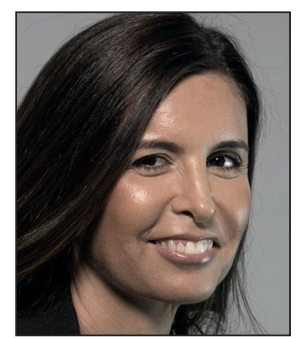

Inma Rodríguez-Ardura https://orcid.org/0000-0002-3310-0214

Universitat Oberta de Catalunya Facultad de Economía y Empresa Av. Tibidabo, 39-43. 08035 Barcelona, Spain irodriguez@uoc.edu

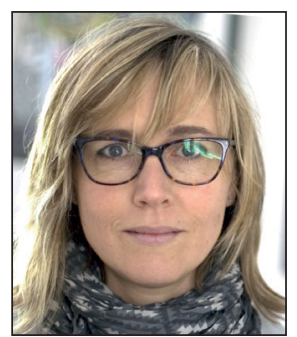

Eva Rimbau-Gilabert https://orcid.org/0000-0002-6786-4300

Universitat Oberta de Catalunya Facultad de Economía y Empresa Av. Tibidabo, 39-43. 08035 Barcelona, Spain erimbau@uoc.edu

\begin{abstract}
Wikipedia is an open educational resource whose frequency of use and importance in higher education are growing. However, empirical evidence about Wikipedia's contribution to students' academic performance is scant and many higher education actors express concern regarding its value. By applying a combined theoretical and empirical approach, we examine the impact of Wikipedia as a primary learning resource on both students' academic performance and the perceived value of Wikipedia. Based on an experimental research design conducted with 2,330 university students, we show that the primary use of Wikipedia in combination with conventional learning resources has a positive effect on students' academic performance, and that this effect is moderated by course discipline. Furthermore, the students' perceived value of Wikipedia is positive and, generally, not influenced by individual academic performance.
\end{abstract}

\section{Keywords}

Wikipedia; Academic performance; Perceived value; Higher education; Open education resources.

Funding

This work received support from the Spanish Government, under Grant No. FCT-14-8269. 


\section{Introduction}

Wikipedia is a major global initiative that offers open access to organised knowledge (Jiménez-Pelayo, 2009; Saorín; Pastor-Sánchez, 2011). In higher education, there is growing interest in using Wikipedia as a learning resource, that is to say, as an instructional resource that can be effectively employed by lecturers for educational purposes. This is not only because Wikipedia has become a recurrent and informal source of information for university students in their academic studies (Selwyn; Gorard, 2016; Minguillón et al., 2017), but also due to initiatives such as the Wikimedia Foundation's Wikipedia Education Program, which fosters the use of Wikipedia for instructional purposes among lecturers. In addition, the mounting pressure on higher education institutions to offer accountability and transparency (Hazelkorn, 2015), as well as the adoption of a market- and student/customer-oriented model (Saichaie; Morphew, 2014; Guilbault, 2018), has led them to step up their use of Wikipedia articles and other open education resources (OERs), which are freely available to educators and students (Butcher, 2011; Atenas-Rivera; Rojas-Sateler; Pérez-Montoro, 2012). Wikipedia, insofar as it provides a vast, public repository of online learning resources (Aibar et al., 2015), is considered to be at the core of the OER movement (De-Freitas; Morgan; Gibson, 2015; Di-Lauro; Johinke, 2017).

Parallel to the advance of Wikipedia in higher education, research in this area has made significant progress in two lines -albeit in a fragmented fashion-. One research stream has focused on the use of Wikipedia to facilitate collaboration and the collective construction of knowledge (Hadjerrouit, 2014; Ricaurte-Quijano; Carli-Álvarez, 2016; Pifarré; Li, 2018). Here, researchers assess the role of students as authors or editors of Wikipedia articles and how these activities enhance aspects such as information searches and evaluation practices (Madden et al., 2012), student knowledge (Sigalov; Nachmias, 2017) and academic writing and literacy skills (Konieczny, 2016).

Another line of research has centred on the use of Wikipedia as a source of instructional content in educational environments and has examined both students' and lecturers' perceptions of it. Some studies have observed the positive attitudes that Wikipedia generates among university students, who appreciate how easy it is to use the platform to search for information and the extensive amount of references and useful content that it offers (e.g. Alonso-de-Magdaleno; García-García, 2013). However, some lecturers have raised concerns about its use as a primary learning tool rather than a casual or complementary resource (Konieczny, 2014; Lladós-Masllorens et al., 2017). They particularly point to knowledge deficiencies in Wikipedia articles (Azer et al., 2015; Zucker; Kontovounisios, 2018) and a lack of reliability and transparency in the user-generated content process (Flanagin; Metzger, 2011). However, these quality perceptions have been found to vary significantly between different fields of knowledge (see Okoli et al., 2014; Mesgari et al., 2015 for reviews). Also, evidence about the educational outcomes of using Wikipedia as an information and learning resource is scant and inconclusive (Ricaurte-Quijano; Carli-Álvarez, 2016; Walker; Li, 2016; Dawe; Robinson, 2017; Di-Lauro; Johinke, 2017) and does not consider the potential interplay between the diverse outcomes of the learning process. Perhaps due to lecturers' concerns and the lack of consistent evidence about the effectiveness of Wikipedia, there are still only a few university courses in which lecturers promote the explicit use of Wikipedia as a primary education resource and assign it an important role in the learning process (Lerga; Aibar, 2015). This paper positions itself within this line of research. More precisely, it aims to contribute a better understanding of the use of Wikipedia as a primary learning resource in higher education and the associated educational consequences.

Given that previous research on this subject is fairly limited, we identify contextual, methodological and relationship-specific opportunities for development. First, the explicit, primary use of Wikipedia (and other OERs) that has been studied refers to contexts in which OERs fully substitute conventional learning resources (see e.g. Hilton III, 2016; Grewe; Davis, 2017). The decision to take this approach may be due to affordability concerns (Allen, 2010) or the notion that using an OER as the single learning resource is a highly innovative teaching practice (Boston Consulting Group, 2013). But, because OERs such as Wikipedia are most often used to supplement, clarify or enrich existing learning resources (Butcher; Hoosen, 2012), our focal context will be the explicit use of Wikipedia in combination with other resources.

Second, as noted by Hilton III (2016) and Grewe; Davis (2017), previous research has suffered from a weak methodological design in terms of the non-random selection of participants, a lack of differentiation between treatment and control groups and small sample sizes. In an attempt to overcome these shortcomings, we will adopt an experimental design that includes treatment and control groups, randomly assigning participants to each group and using a reasonably large enough sample.

Third, we will elaborate and extend the nomological network surrounding the primary use of Wikipedia in a way that is consistent with the great importance that universities place on assessing educational outcomes (Praslova, 2010; Tam, 2014). Previous studies have highlighted the importance of the perceived value that students give to key elements of the educational environment and have suggested that students' value judgements are a contributing factor to their satisfaction (Hsu et al., 2016; Doña-Toledo; Luque-Martínez; Del-Barrio-García, 2017) and, ultimately, to their willingness to continue at the university (Rodríguez-Ardura; Meseguer-Artola, 2016). Based on this reasoning, our nomological network will include potential causal links explaining students' perceptions of the value of Wikipedia. Furthermore, we will consider the mediating role of another potential major consequence of the primary use of Wikipedia-students' academic performance-. Additionally, to provide a more nuanced understanding of the impact of using Wikipedia, we will examine the potential moderating role of course disciplines. 


\section{Theoretical background}

In this section, we discuss the theoretical considerations that have led us to propose our conceptual model. To theoretically explain the mediating and causal pathways that influence how students form a positive perception of the value of Wikipedia, we use theoretical accounts of multiple-text reading comprehension, such as the documents model framework and service management and consumer behaviour literature on perceived value. Furthermore, previous bibliometric analyses of Wikipedia and research into disciplinary differences in educational assessment offer theoretical support for including the interactive effects of course discipline in the model (see Figure 1).

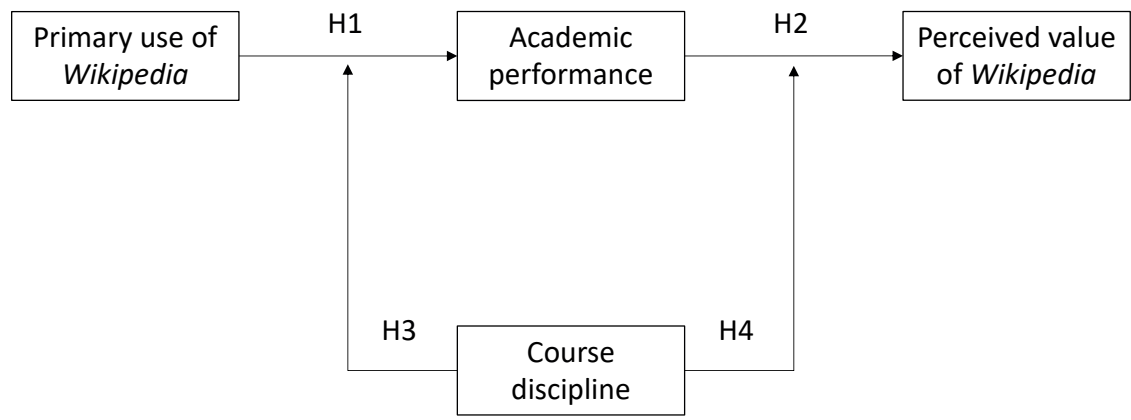

Figure 1. Conceptual model: the primary use of Wikipedia influences students' academic performance and the perceived value of Wikipedia

\subsection{Academic impact of the primary use of Wikipedia}

On the rare occasions in which lecturers prescribe the use of Wikipedia as a primary learning resource in their courses, Wikipedia is commonly used in combination with other didactic materials to clarify, set the stage for or complement the information provided by more conventional learning resources such as textbooks, case studies and articles (Aibar et al., 2015; Selwyn; Gorard, 2016). This combined use of Wikipedia with other primary didactic materials is consistent with contemporary views of education that claim that learning processes are less about consulting a single didactic material and performing prearranged tasks and more about critically evaluating and interpreting a multitude of didactic tools, solving complex problems and contributing to or co-creating learning experiences (see Rasmussen; Damşa, 2017).

For students required to use a variety of information and learning resources, the challenge might be how to meaningfuIly connect, organise and integrate information from these different sources in order to build their knowledge (Barzilai; Zohar; Mor-Hagani, 2018). Based on theoretical accounts of multiple-text reading comprehension (Wineburg, 1991; Rouet, 2012), such as Britt; Rouet (2012)'s documents model framework, we could deduce that by integrating and comprehending Wikipedia content, along with various other didactic materials, students obtain higher levels of understanding. This is because in their endeavour to coherently understand a given central issue, problem or phenomenon, students handle multiple resources that often present fragmented, distinct or discrepant information or vary in their design and trustworthiness (Richter; Maier, 2017; Bråten; Braasch; Salmerón, 2020). To construct consistent knowledge, students integrate the information from individual learning resources as well as across multiple resources (Britt; Rouet, 2012) and build a mental representation of the contributions of each individual resource (Britt et al., 1999); when facing inconsistencies, they exhibit intense gaze behaviour and reactivate previously read content to integrate it (Schüler, 2019). This, in turn, facilitates a deeper and more complete understanding of the topic of study, encompassing various perspectives and insights (Farmer, 2019).

Previous studies on multiple-source comprehension offer evidence of its positive impact on learning (Goldman et al., 2012; Braasch; Bråten; McCrudden, 2018). For example, Palmer; Stewart (1997) showed that the use of a variety of non-fiction books allowed students to examine a single topic in depth, while synthesising information, enhancing critical thinking skills and acquiring more in-depth knowledge. In a longitudinal study, Strømsø; Bråten; Samuelstuen (2003) detected that students with the highest grades in a law course made more intertext connections between various information sources. Winkel et al. (2006) reported that courses with a greater number of primary resources were associated with a longer study time and higher grades. Zhang (2018) found that a combination of OERs with a textbook in English as a foreign language helped students to acquire language knowledge. Also, an exploratory study for a course in statistics observed a better performance among the students required to use Wikipedia together with conventional learning resources than for their peers who used only regular didactic materials (Meseguer-Artola, 2014). Consistent with this, we propose the following hypothesis:

H1: The primary use of Wikipedia (in combination with other learning resources) has a positive effect on academic performance 


\subsection{The students' perceived value of Wikipedia}

As suggested by research on students' information behaviour (e.g. Sin, 2016), most online and social media function as mere disseminating and sharing venues for short pieces of information and opinions. This might explain why university students use these media only in the preliminary stages of information seeking (Selwyn; Gorard, 2016) while questioning their completeness, reliability and up-to-dateness as sources of information (Kim; Sin; Tsai, 2014). But, because Wikipedia is specifically devoted to the co-creation of original and accurate content, it is not generally viewed by students as a conventional online or social media tool but rather as a unique source of valuable "long-form, original information" (Selwyn; Gorard, 2016).

Wikipedia generates value for university students in a variety of ways. First, it may be useful to students as it allows them to obtain suitable information for building their own knowledge (Back et al., 2016; Soler-Adillon; Pavlovic; Freixa, 2018). As a matter of fact, Wikipedia is widely used by students to obtain background and introductory information in order to gain a quick content overview (Kim; Sin; Tsai, 2014); it is also used to obtain more specific information to clarify issues (Selwyn; Gorard, 2016). This utility benefit of Wikipedia may be particularly apparent among students who are most experienced in using it (Sigalov; Nachmias, 2017; Soler-Adillon; Pavlovic; Freixa, 2018) or those who have a higher capacity to evaluate the usefulness of the information obtained (Madden et al., 2012; Kim; Sin; Tsai, 2014). Second, Wikipedia might offer greater value than conventional learning resources (Knight; Pryke, 2012; Kennedy et al., 2015) since it offers the possibility to easily obtain complete, reliable and up-to-date information (Lim, 2009). This is because Wikipedia is widely accessible to students and, even more importantly, students can directly look up the external links and abundant references cited in the articles and check their accuracy (Becker, 2015). In other words, the numerous links and references available in Wikipedia contribute to enhancing students' perception of Wikipedia as a complete and reliable content source (Mesgari et al., 2015). Another positive aspect is that Wikipedia facilitates students' access to up-to-date information (Okoli et al., 2014). Even when dealing with old information, Wikipedia articles have proven to be more up to date than other sources (Mesgari et al., 2015). Furthermore, Wikipedia provides these benefits at a minimum cost since it is a free and open resource that is easy to use (Hilton III, 2016).

On the basis of service management and consumer behaviour literature (Lam et al., 2004; Lee; Chung; Lee, 2012), the value that students attribute to Wikipedia can be conceived as a cognition-based construct that captures the perceived net benefits arising from students' use of Wikipedia. That is to say, the students' perceived value of Wikipedia indicates a potential trade-off between what Wikipedia provides students with and the time and efforts students invest when using it. Therefore, a high perceived value of Wikipedia results from the students' view that it offers important net benefits, in terms of utility and convenience, for obtaining complete, reliable and up-to-date information.

A potential causal connection between students' academic performance and the perceived value of Wikipedia can be established since academic performance is considered to be one of the most important learning outcomes (York; Gibson; Rankin, 2015) and, therefore, a central source of value creation for students. Essentially, a student's academic performance will determine if he or she graduates and even influence his or her entry into high-level occupations (Cai, 2013; Pinto; Ramalheira, 2017). In order for Wikipedia to provide superior perceived value, it should be able to meet students' expressed and latent learning requirements. To enable this to occur, academic performance is crucial.

Even though students' experience of using Wikipedia as a learning resource potentially enhances the understanding of its benefits (Soler-Adillon; Pavlovic; Freixa, 2018), the specific connections between academic performance and the perceived value of Wikipedia have not yet been explored. However, some recent studies have found evidence linking students' improved cognitive outcomes with positive judgements of the educational environment as a whole (Dužević; Mikulić; Baković, 2016; Wilkins et al., 2016; Luque-Martínez; Doña-Toledo, 2019). We therefore propose the following hypothesis:

H2: Academic performance has a positive effect on the perceived value of Wikipedia

As suggested by Hilton III (2016), the causal connection between students' academic performance and the value they attribute to OERs such as Wikipedia might be accentuated by students' opinions and perceptions of the learning environment. This might occur when academic performance, rather than being operationalised through objective, register variables, is measured with subjective scales (Pike, 1999) that assess how students evaluate their learning results.

Because learning is a socially desirable outcome (Podsakoff; MacKenzie; Podsakoff, 2012), a halo effect may exist if it is measured along with other constructs related to the learning experience (Rodríguez-Ardura; Meseguer-Artola, 2017). To discard this possibility and provide hard evidence about the potential influence of academic performance on the perceived value of Wikipedia, we will not operationally define academic performance as the students' own evaluation of their learning results but will rather use an objective operationalisation of academic performance.

\subsection{Differences between course disciplines}

Research has not yet examined the potential moderating role of course discipline on the influence that a primary use of Wikipedia has on academic performance or the interaction effects of course discipline with academic performance and perceived value. However, the specificities of the knowledge domain and the departments within the university might have a relevant impact on the outcomes of students' learning experiences and perceptions (Umbach; Porter, 2002; Kim; Sax, 2014). 
Differences in Wikipedia content across disciplines have been explored in previous bibliometric studies (Halavais; Lackaff, 2008; Park, 2011; Tohidinasab; Jamali, 2016; Tomaszewski; MacDonald, 2016), which have revealed that some specific issues within disciplines are covered more comprehensively and accurately than others. For example, in an examination of citations of Wikipedia in scholarly publications indexed in the Web of Science databases between 2002 and 2016, Tomaszewski; MacDonald (2016) detected that the Social Sciences Citation Index had the highest rate of Wikipedia citations (4.5 per cent of journals in the Index cited Wikipedia articles), closely followed by the Science Citation Index (4.2 per cent of the indexed journals); whereas the Arts \& Humanities Citation Index had the lowest rate of citations (3.4 per cent of the journals). In line with this, lecturers' views of Wikipedia vary across disciplines. For example, Eijkman (2010) noticed more sceptical assessments among lecturers in soft sciences than among their hard science peers; Aibar et al. (2015) reported a more intense and sophisticated use of Wikipedia in teaching practices by lecturers in natural sciences and engineering than among those who teach courses in the humanities, social sciences and law. Considering these differences, it seems reasonable to expect that students taking courses in distinct domains of knowledge benefit differently from their use of Wikipedia.

H3: Course discipline moderates the effect of primary use of Wikipedia (in combination with other learning resources) on academic performance.

Academic disciplines differ in the cognitive processes they generate, the teaching methods they put in place, the extent to which theoretical considerations are applied in practice or their emphasis on research (Kember; Leung, 2011; Adler et al., 2016). Students who find some disciplines or topics very demanding or feel that they involve more coursework may be less likely to attribute a higher net value to them (Denson; Loveday; Dalton, 2010). This is consistent with the "rigor paradox" (Clayson, 2009), which suggests that students tend to reward courses where they are marked more leniently (Centra, 2003; Brockx; Spooren; Mortelmans, 2011) or less challenging courses that require lower levels of effort and preparation (Thornton; Adams; Sepehri, 2016).

Because course disciplines differ in their difficulty and teaching methods, we suggest that course discipline is a factor that interacts with academic performance and moderates the causal relationship between academic performance and perceived value.

H4: Course discipline moderates the effect of academic performance on the perceived value of Wikipedia

\section{Methodology}

Because rigorous experimental design is the proper choice for studies that seek to examine the causal effects of innovation interventions on the outcomes of learning processes (Longva; Foss, 2018), we used a field experiment to test the four hypotheses of the conceptual model regarding: the direct and indirect impact of the active use of Wikipedia as an instructive resource $(\mathrm{H} 1, \mathrm{H} 2)$; the moderating role of the course discipline $(\mathrm{H} 3, \mathrm{H} 4)$. This approach allowed us to create a test scenario that manipulates the cardinal use of Wikipedia in a real-world higher education environment. Therefore, results of this study have strong external validity.

\subsection{Participants and design}

The participants were 2,330 university students who took part in the experiment. We manipulated the primary use of Wikipedia (using Wikipedia versus not using Wikipedia) in a $4 \times 2$ between-course discipline design. The conditions were derived by combining undergraduate courses in four disciplines (Consumer Behaviour, Human Resources, Marketing and Statistics) with tasks and activities divided into two groups, whereby one group used Wikipedia as a primary learning resource and the other did not.

\subsection{Stimulus and procedure}

All participants were students enrolled in bachelor's programmes in business administration, tourism or marketing at a fully-online European university. They were taking a course in one of the four selected disciplinary groups (i.e. Consumer Behaviour, Human Resources, Marketing or Statistics), which were all in the curriculum of their bachelor's programmes. In each course, participants were instructed to complete five assignments and take a final exam to earn course credit.

Participants in the non-Wikipedia condition were not specifically asked to use Wikipedia to prepare their assignments (i.e. the lecturers explicitly mentioned only conventional didactic materials to be used); whereas students in the Wikipedia condition had to perform two out of five assignments by using Wikipedia along with other core learning resources (e.g. e-books, business cases, conventional articles and computer simulators). The assignments that required the use of Wikipedia were uniform across the four courses and consisted in comparing a specific Wikipedia article with the conventional didactic materials used in the course. Each Wikipedia article had been previously selected by the corresponding course lecturer or lecturers, and addressed the main topics, issues or problems tackled in the assessment.

Table 1. Student distribution

\begin{tabular}{|l|c|c|}
\hline Course discipline & Using Wikipedia & Not using Wikipedia \\
\hline Consumer Behaviour & 290 & 235 \\
\hline Human Resources & 510 & 479 \\
\hline Marketing & 44 & 38 \\
\hline Statistics & 388 & 346 \\
\hline Total & 1,232 & 1,098 \\
\hline
\end{tabular}


Participants in each course were randomly assigned to one of the two groups defined by the use (or not) of Wikipedia. The distribution of students by course discipline and active Wikipedia use is shown in Table 1.
We propose a conceptual model of the primary use of Wikipedia as a learning resource

\subsection{Data collection and measurement}

Data from the participants in the experiment was gathered through two sources of information: the university's registrar office and an online questionnaire. The registrar office provided the data on the students' academic performance in the four undergraduate courses under study (Consumer Behaviour, Human Resources, Marketing and Statistics), the students' overall satisfaction with every course and their satisfaction with the didactic resources used in each course.

Student's academic performance was measured by the final mark attained in the course and ranged from 1 (unsatisfactory) to 10 (excellent work). Student's overall satisfaction and student's satisfaction with didactic resources were both drawn from the online student evaluation of teaching (SET) survey, conducted by the registrar office at the end of the academic semester. The two satisfaction items were measured through a 5-point Likert scale ranging from 1 (not satisfied at all) to 5 (completely satisfied).

An online questionnaire was used to collect the data about the participants' perceived value of Wikipedia. The questionnaire was included in two out of the five assignments of the students enrolled in the courses using Wikipedia. To measure the students' perceived value, we adapted Meseguer-Artola et al. (2016)'s scale, whose items were originally developed by Shen; Cheung; Lee (2013) and Sussman; Siegal (2003). This scale considers four dimensions of perceived value: usefulness, completeness, reliability and up-to-dateness (see Table 2). Respondents had to rate their answers using a 5-point Likert scale ranging from 1 (strongly disagree) to 5 (strongly agree).

Table 2. Questionnaire measurement scale of perceived value of Wikipedia

\begin{tabular}{|l|l|}
\hline \multicolumn{1}{|c|}{ Dimensions } & \\
\hline Usefulness & (PV1) Has Wikipedia been useful in helping you meet the learning objectives of this assignment? \\
\hline Completeness & $\begin{array}{l}\text { (PV2) In comparison with the other course learning resources, do you think that Wikipedia gave you a complete view of } \\
\text { the issues being studied? }\end{array}$ \\
\hline Reliability & $\begin{array}{l}\text { (PV3) In comparison with the other course learning resources, do you think that Wikipedia provided you with reliable } \\
\text { information about the issues being studied? }\end{array}$ \\
\hline Up-to-dateness & $\begin{array}{l}\text { (PV4) In comparison with the other course learning resources, do you think that the information in Wikipedia was up to } \\
\text { date? }\end{array}$ \\
\hline
\end{tabular}

Since each perceived value dimension was measured twice (i.e. in two assignments), the value of the associated item resulted from the mean of the two answers obtained. Hence, the construct was measured through four items (PV1, PV2, PV3 and PV4) and computed as the mean of the Qi dimension scores obtained in the two assignments:

$$
P V i=\frac{Q i_{\text {assessment A }}+Q i_{\text {assessment B }}}{2}, i=1,2,3,4
$$

\section{Tests and results}

To empirically examine the validity of hypotheses $\mathrm{H} 1$ and $\mathrm{H} 3$ of our model, we used t-tests on data gathered from all students in the $4 \times 2$ groups (i.e. 2,330 students). This allowed us to determine whether there were significant differences between the groups in which Wikipedia was used as a primary learning resource and the others in which Wikipedia was not explicitly used.

The mean final mark for the groups of students using Wikipedia was 6.85 and for those groups not using Wikipedia was 6.13 (see Table 3). Across course disciplines, students in the two groups who took the marketing course achieved the highest marks: marketing students actively using Wikipedia earned a mean final grade of 7.62 and students not using it, 7.21. At the other end, we found that the final grade of each group of students enrolled in statistics was below the overall mean.

The result of a two-sample t-test for equal means $(t=12.76, p=0.00)$ confirmed that there was a statistical difference between the final grades of the students actively using Wikipedia and those not using it. Because the value of the mean was higher for the users' group (versus the non-users' group), we deemed that academic performance was higher when Wikipedia is included in the course design.

To test the moderator effect of course discipline on the causal connection between Wikipedia use and academic performance, we considered the mean scores of the final marks in each of the $4 \times 2$ groups and the differences between course disciplines. The t-tests showed that final marks were generally higher for students who used Wikipedia ( $p$-values $<0.05)$, and also that the intensity of the effect of Wikipedia use differed across courses: the t-statistics were clearly distinct from each other, especially in the cases of Marketing and Statistics (with greater p-values than courses in Consu- 
mer Behaviour and Human Resources). Furthermore, participants who took courses in Consumer Behaviour and Human Resources benefited more academically from using Wikipedia than students enrolled in the other two courses. All of this suggests that course discipline plays a moderating role in the influence that Wikipedia use has on academic performance and hence $\mathrm{H} 3$ is supported.

Table 3. Influence of Wikipedia use on overall final marks and across course disciplines

\begin{tabular}{|c|c|c|c|c|c|c|}
\hline & Mark & t-test & Course discipline & Mark & Difference & t-test \\
\hline \multirow{4}{*}{ Using Wikipedia } & \multirow{4}{*}{6.846} & $12.759^{*}$ & Consumer Behaviour & 6.885 & +0.904 & $9.223^{*}$ \\
\hline & & & Human Resources & 7.117 & +0.705 & $8.120^{*}$ \\
\hline & & & Marketing & 7.620 & +0.407 & $2.250^{* * *}$ \\
\hline & & & Statistics & 6.378 & +0.634 & $5.828^{*}$ \\
\hline \multirow{4}{*}{ Not using Wikipedia } & \multirow{4}{*}{6.130} & & Consumer Behaviour & 5.981 & & \\
\hline & & & Human Resources & 6.412 & & \\
\hline & & & Marketing & 7.213 & & \\
\hline & & & Statistics & 5.744 & & \\
\hline
\end{tabular}

${ }^{*}$ p-value $=0.000, *$ p-value $=0.030$

To examine $\mathrm{H} 2$ and $\mathrm{H} 4$, we conducted analyses on the subsample of the 1,232 students who used Wikipedia as a primary learning resource. Preliminary results on the perceived value of Wikipedia indicated that up-to-dateness was the most valued dimension, followed by usefulness (Table 4). The less valued components were completeness (with a mean score below 3 ) and reliability (very close to the middle score). Pairwise samples t-tests showed that differences in perceived value were significant between completeness and reliability, but not between usefulness and up-to-dateness.

Table 4. Mean scores of perceived value items and tests for differences

\begin{tabular}{|l|c|c|c|c|}
\cline { 3 - 5 } \multicolumn{1}{|c|}{} & \multicolumn{2}{c|}{ Pairwise samples t-test } \\
\hline Items & Mean & s.d. & PV2 & PV3 \\
\hline Usefulness PV1 & 3.193 & 1.137 & $-12.536^{*}$ & $-3.651^{*}$ \\
\hline Reliability PV3 & 2.780 & 0.934 & & $-8.270^{*}$ \\
\hline Up-to-dateness PV4 & 3.049 & 1.010 & & $-13.171^{*}$ \\
\hline
\end{tabular}

$*$ p-value $<0.050$

We divided participants into three groups according to their academic performance: low-performing students (whose final marks were lower than 6), medium-performing students (with final marks between 6 and 8) and high-performing students (with marks higher than 8). The descriptive statistics of the items for each performance group did not yield great differences between groups (see total results in Table 5). After comparing these results with the general results (Table 4), we found that the most valued dimension of Wikipedia in each group was its up-to-dateness (completeness was the least valued facet). Although these perceptions prevailed in all course disciplines, differences between performance

Table 5. Mean and standard deviation of the items for each performance group

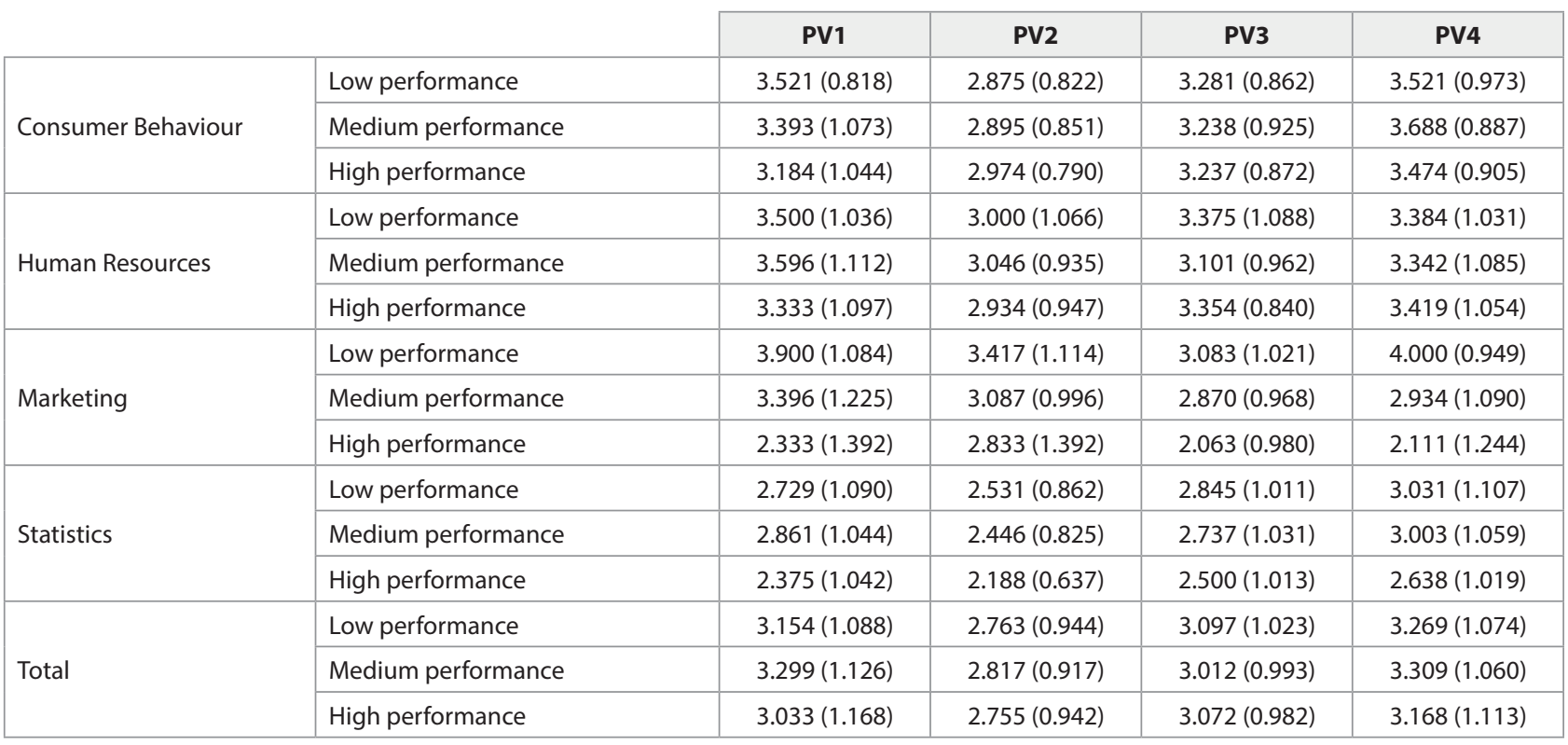


groups were greater for students who took marketing and statistics courses. Particularly, high-performing students in Marketing and Statistics gave the lowest scores in all four items related to perceived value, but this was not the case in the other two disciplines.

Since perceived value is a latent variable measured with four items, we checked its internal reliability and convergent validity (Table 6). First, the Cronbach's $\alpha$ value was clearly above the minimum 0.70 level required, and the item-total correlations were greater than the recommended cut-off of 0.50 (Hair et al., 2010) -all of which demonstrated the construct's good reliability-. Second, the factor analysis of the four items showed that there was just one component with an eigenvalue greater than $1(\lambda=2.35)$, which retained $58.74 \%$ of the information contained in the initial variables, and all factor loadings were greater than 0.70. We thus inferred that convergent validity was achieved (Hair et al., 2010).

Table 6. Internal reliability and convergent validity

\begin{tabular}{|c|c|c|c|}
\hline Items & Cronbach's a & Item-total correlations & Factor loadings \\
\hline PV1 & 0.763 & 0.599 & 0.797 \\
\hline PV2 & & 0.569 & 0.770 \\
\hline PV3 & & 0.563 & 0.764 \\
\hline PV4 & & 0.529 & 0.734 \\
\hline
\end{tabular}

After ensuring that the composite of the four scale items was adequate for measuring the students' perceived value of Wikipedia, we assessed its relationship with academic performance and course discipline by means of anova analyses.

For each performance group, we computed the mean scores of the projection of the perceived value for every student onto the principal component of the construct. In the total case, the p-value of the anova was clearly higher than 0.05 (Table 7). This indicated that there were no significant differences between groups, so perceived value does not depend on academic performance. Nevertheless, significant differences did exist between groups in the course disciplines in Marketing and Statistics (with p-values lower than 0.05). According to the descriptive statistics (Table 5), high-performing students in Marketing and Statistics had the lowest perceived value. Therefore, the moderator effect of course discipline on the relationship between academic performance and perceived value was confirmed ( $\mathrm{H} 4)$. In addition, $\mathrm{H} 2$ was partially supported for the courses in Marketing and Statistics - precisely those within which students benefited less from Wikipedia use-.

Table 7. Anova tests for the differences in perceived value between groups

\begin{tabular}{|c|c|c|c|c|c|c|}
\hline & & & & & & \\
\hline & & Sum of squares & d.f. & Mean square & $\mathbf{F}$ & p-value \\
\hline \multirow{3}{*}{ Consumer Behaviour } & Between groups & 0.191 & 2 & 0.095 & 0.136 & 0.873 \\
\hline & Within groups & 142.309 & 203 & 0.701 & & \\
\hline & Total & 142.500 & 205 & & & \\
\hline \multirow{3}{*}{ Human Resources } & Between groups & 0.238 & 2 & 0.119 & 0.132 & 0.876 \\
\hline & Within groups & 307.193 & 341 & 0.901 & & \\
\hline & Total & 307.431 & 343 & & & \\
\hline \multirow{3}{*}{ Marketing } & Between groups & 11.135 & 2 & 5.567 & 5.292 & 0.010 \\
\hline & Within groups & 34.716 & 33 & 1.052 & & \\
\hline & Total & 45.851 & 35 & & & \\
\hline \multirow{3}{*}{ Statistics } & Between groups & 6.503 & 2 & 3.252 & 3.655 & 0.027 \\
\hline & Within groups & 266.039 & 299 & 0.890 & & \\
\hline & Total & 272.542 & 301 & & & \\
\hline \multirow{3}{*}{ Total } & Between groups & 2.400 & 2 & 1.200 & 1.230 & 0.293 \\
\hline & Within groups & 863.672 & 885 & 0.976 & & \\
\hline & Total & 866.071 & 887 & & & \\
\hline
\end{tabular}

We took a closer look at the students' perceived value of Wikipedia across course disciplines (see Table 8). First, we found that students that gave the lowest scores to Wikipedia's value were the ones taking a course in Statistics -which can be considered as an applied, yet hard, science (Biglan, 1973)-. More precisely, statistics students assigned the poorest ratings to the perceived value's dimensions of usefulness, completeness and reliability. Also, they rated all four dimensions of Wikipedia's value with scores below the middle level of 3. On the opposite side of the ledger, the students on consumer behaviour and human resources courses allotted the greatest marks to the perceived value dimensions of usefulness, reliability and up-to-dateness.

Overall, the significant differences obtained in Wikipedia's perceived value across various course disciplines were consistent with the "rigor paradox" (Clayson,
We conduct an experimental design using a sample of 2,330 students 
2009) and previous evidence pointing to disciplines' role in students' academic perceptions (Kim; Sax, 2014). It became apparent that the active use of Wikipedia in a not-soft, quantitative course like Statistics tended to elicit the poorest ratings. However, the question was whether these results could be attributed only to the intrinsic difficulty of the course or also to the instructional practices that the lecturer puts in place-particularly the teaching strategies he or she implements to integrate Wikipedia with other didactic materials and use them successfully-.

Second, to shed some additional light on the potential connection of Wikipedia's value with the educational service provided by the lecturer, we compared the students' perceptions of Wikipedia to the SET data on students' overall satisfaction with the course and to the students' satisfaction with the whole set of learning resources used in the course. As seen in Table 8, students' perceptions on Wikipedia were positively correlated with the SET data across all discipline courses. Yet, compared with the rest of disciplines, statistics students had the worst satisfaction levels.

Table 8. Student satisfaction and perceived value of Wikipedia across disciplines

\begin{tabular}{|c|c|c|c|c|c|c|}
\hline \multirow{2}{*}{ Course discipline } & \multirow{2}{*}{$\begin{array}{l}\text { Overall satisfaction with } \\
\text { the course }\end{array}$} & \multirow{2}{*}{$\begin{array}{l}\text { Satisfaction with the } \\
\text { learning resources }\end{array}$} & \multicolumn{4}{|c|}{ Perceived value of Wikipedia } \\
\hline & & & PV1 & PV2 & PV3 & PV4 \\
\hline Consumer Behaviour & 3.82 & 3.66 & 3.39 & 2.88 & 3.27 & 3.61 \\
\hline Human Resources & 4.02 & 3.95 & 3.47 & 2.98 & 3.23 & 3.35 \\
\hline Marketing & 3.71 & 3.54 & 3.21 & 3.08 & 2.73 & 2.91 \\
\hline Statistics & 3.58 & 3.22 & 2.75 & 2.45 & 2.73 & 2.96 \\
\hline
\end{tabular}

Third, it became clear that the perceived value of Wikipedia was largely positive across disciplines but slightly lower than the SET satisfaction scores it was compared to (i.e. overall course satisfaction, satisfaction with the learning resources). This suggests that additional effort should be made to better embed Wikipedia in the set of didactic resources offered to students. Indeed, lecturers should pay special attention to the completeness of the Wikipedia articles they choose for their courses, since this was the quality aspect of Wikipedia that received the lowest ratings (except among marketing students).

\section{Concluding remarks}

This paper examines the academic and perceived value effects of using Wikipedia as a primary learning resource, not to fully substitute conventional textbooks and didactic tools but rather to be used in combination with them -since this is the most common and natural case-. Overall, it contributes to a more systematic comprehension of the educational impact of Wikipedia in three ways.

Firstly, it proposes a novel research framework for studying the outcomes of Wikipedia use in education, integrating multiple-text reading comprehension theories and service management and consumer behaviour perspectives into theoretical accounts in higher education assessment. In essence, the results from empirically testing this integrative approach suggest that Wikipedia has a positive impact on students' academic performance. The results also suggest that students' perceptions of Wikipedia are largely shaped by the course discipline; however, they are only circumstantially influenced by enhanced academic performance on the course.

Our findings regarding the positive value that students attribute to Wikipedia as a learning resource mirror and complement those of Soler-Adillon; Pavlovic; Freixa (2018), who considered students' use of Wikipedia in content co-creation. More specifically, our results show that students perceive Wikipedia to be an up-to-date, reliable and useful didactic material. However, they deem that Wikipedia articles offer room for improvement in terms of com-

\section{Wikipedia enhances students' academic performance}

pleteness -particularly when compared with conventional learning resources-. What is more, students' appreciation of Wikipedia's learning benefits is somewhat lower than that garnered by established didactic materials and does not depend on the student's academic success in the course.

The second contribution is made by extending multiple-text reading comprehension theories, not only by including the consequences of processing, integrating and applying information on students' academic performance but also by yielding insights about how the enrichment of using diverse sources of information in the learning process interacts with course disciplines.

Thirdly, and lastly, this study adds a line of evidence to the educational assessment debate about the relationship between learning and students' evaluation of the educational environment. To minimise the risk of common method bias -so disconcertingly apparent in previous studies- we measured learning objectively in order to eliminate any source of halo effect interfering with the potential interplay of student performance and perceived value. Our results echo those observed in Clayson's (2009) meta-analysis of the literature insofar as they demonstrate that the average relationship between learning and students' perceptions is insignificant and reveal that this path is more circumstantial. On the one hand, we did not find full support in our data sample for a direct causal relationship between academic performance and perceived value. On the other hand, we detected significant statistical differences in perceived value between students' 
performance profiles for some specific course disciplines. Indeed, the students' perceived value of Wikipedia was significantly higher in the two courses where the positive academic impact of using Wikipedia was more pronounced (Consumer Behaviour and Human Resources).

Furthermore, the study has some important limitations that offer opportunities for further research. First, we did not assess the role of student engagement, which could mediate the relationship between academic performance and perceived value. Engagement may act as a pathway to academic success (Picton; Kahu; Nelson, 2018) and involve aspects of the educational experience not considered here, including a student's commitment, self-efficacy and positive affect (Kahu; Nelson, 2018). In turn, the potential role of engagement might be influenced not only by academic performance but also by other factors such as personality (Strahan; Credé, 2015).

Second, our data was collected from 2,230 students in a non-comprehensive set of course disciplines of bachelor's programmes at a fully-online university. The relatively narrow range of courses, programmes and educational methods considered in the empirical study contributes to have small variance in the model estimation remaining unexplained; so it might increase the power of hypothesis tests. However, it has limited external validity. Future research might therefore assess whether the observed causal and moderating relationships should be generalised to and across a wider spectrum of disciplines, educational settings and times.

Third, the direction of the causal path from academic performance to perceived value is based on the assumption that enhanced performance, due to the use of Wikipedia, can provide students with additional academic value, thus leading to a higher perceived value of Wikipedia. Due to the possibility of cross-category variation in this relationship, the sample size of future studies should be increased to further examine this variation. Added to this, subsequent research could explore whether this relationship might also be the other way round. The theory of planned beThe perceived value of Wikipedia is moderated by course discipline

haviour (Ajzen; Fishbein, 2014) gives grounds for the alternative notion that students' evaluation of Wikipedia could explain their future behaviour in terms of academic performance.

This research may help lecturers and higher education professionals dismiss their concerns about Wikipedia and promote its inclusion in the core portfolio of effective learning resources. We recommend that higher education actors encourage the use of Wikipedia as a primary education resource in combination with conventional didactic materials in order to provide students with an enriched diversity of information and learning resources.

\section{References}

Adler, Ralph; Crombie, Neil; Dixon, Keith; Roberts, Helen (2016). "Lecturing and learning in accounting: interpreting intricacy". In: $8^{\text {th }}$ Asia-Pacific interdisciplinary research in accounting conference.

https://www.academia.edu/26520023/Lecturing_and_Learning_in_Accounting_Interpreting_Intricacy

Aibar, Eduard; Lladós-Masllorens, Josep; Meseguer-Artola, Antoni; Minguillón, Julià; Lerga, Maura (2015). “Wikipedia at university: what faculty think and do about it". The electronic library, v. 33, n. 4, pp. 668-683.

https://doi.org/10.1108/EL-12-2013-0217

Ajzen, Icek; Fishbein, Martin (2014). "The influence of attitudes on behavior". In: Albarracín, Dolores; Johnson, Blair T.; Zanna, Mark P. (eds.). The handbook of attitudes. Psychology Press, pp. 173-222. ISBN: 9781135626167 https://www.researchgate.net/publication/264000974_The_Influence_of_Attitudes_on_Behavior

Allen, Nicole (2010). A conver to cover solution: how open textbooks are the path to textbook affordability. https://hewlett.org/wp-content/uploads/2016/08/A-Cover-To-Cover-Solution.pdf

Alonso-de-Magdaleno, María-Isabel; García-García, Jesús (2013). “Colaboración activa en Wikipedia como método de aprendizaje". Revista iberoamericana de educación a distancia, v. 16, n. 1, pp. 13-26.

https://doi.org/10.5944/ried.16.1.2056

Atenas-Rivera, Javiera; Rojas-Sateler, Francisco; Pérez-Montoro, Mario (2012). "Repositorios de recursos educativos abiertos". El profesional de la informacion, v. 21, n. 2, pp. 190-193.

https://doi.org/10.3145/epi.2012.mar.10

Azer, Samy A.; Alswaidan, Nourah M.; Alshwairikh, Lama A.; Alshammari, Jumana M. (2015). "Accuracy and readability of cardiovascular entries on Wikipedia: are they reliable learning resources for medical students?". BMJ open, v. 5, n. 10. https://doi.org/10.1136/bmjopen-2015-008187

Back, David A.; Behringer, Florian; Haberstroh, Nicole; Ehlers, Jan P.; Sostmann, Kai; Peters, Harm (2016). "Learning management system and e-learning tools: an experience of medical students' usage and expectations". International journal of medical education, v. 7, pp. 267-273.

https://doi.org/10.5116/ijme.57a5.f0f5 
Barzilai, Sarit; Zohar, Asnat R.; Mor-Hagani, Shiri (2018). "Promoting integration of multiple texts: a review of instructional approaches and practices". Educational psychology review, v. 30, n. 3, pp. 973-999.

https://doi.org/10.1007/s10648-018-9436-8

Becker, Bernd W. (2015). "Research faux pas: the stigma of Wikipedia". Behavioral \& social sciences librarian, v. $34, \mathrm{n}$. 3, pp. 165-169.

https://doi.org/10.1080/01639269.2015.1062587

Biglan, Anthony (1973). "The characteristics of subject matter in different academic areas". Journal of applied psychology, v. 57, n. 3, pp. 195-203.

https://doi.org/10.1037/h0034701

Boston Consulting Group (2013). The open education resources ecosystem: an evaluation of the OER movement's current state and its progress toward mainstream adoption.

https://www.hewlett.org/wp-content/uploads/2016/08/The\%200pen\%20Educational\%20Resources\%20Ecosystem.pdf

Braasch, Jason L. G.; Bråten, Ivar; McCrudden, Matthew T. (2018). "Introduction to research on multiple source use". In: Braasch, Jason L. G.; Bråten, Ivar; McCrudden, Matthew T. (eds.). Handbook of multiple source use. New York: Routledge, pp. 1-13. ISBN: 9781315627496

https://doi.org/10.4324/9781315627496-1

Bråten, Ivar; Braasch, Jason L. G; Salmerón, Ladislao (2020). "Reading multiple and non-traditional texts: new opportunities and new challenges”. In: Kamil, Michael L.; Pearson, P. David; Moje, Elizabeth B.; Afflerbach, Peter P. (eds.). Handbook of reading research, v. 5, pp. 79-98. New York: Routledge. ISBN: 9780805853421

Britt, M. Anne; Perfetti, Charles A.; Sandak, Rebecca; Rouet, Jean-François (1999). "Content integration and source separation in learning from multiple texts". In: Goldman, Susan R.; Graesser, Arthur C.; Van-den-Broek, Paul (eds.). Narrative comprehension, causality, and coherence. Essays in honor of Tom Trabasso, pp. 209-233. ISBN: 9780415761635

Britt, M. Anne; Rouet, Jean-François (2012). "Learning with multiple documents: component skills and their acquisition". In: Kirby, John R.; Lawson, Michael J. (eds.). Enhancing the quality of learning: dispositions, instruction, and learning processes. Cambridge Univesity Press, pp. 276-314. ISBN: 9780521145497

https://doi.org/10.1017/CBO9781139048224.017

Brockx, Bert; Spooren, Pieter; Mortelmans, Dimitri (2011). "Taking the grading leniency story to the edge. The influence of student, teacher, and course characteristics on student evaluations of teaching in higher education". Educational assessment, evaluation and accountability, v. 23, n. 4, pp. 289-306.

https://doi.org/10.1007/s11092-011-9126-2

Butcher, Neil (2011). A basic guide to open educational resources (OER). Vancouver, BC: Commonwealth of Learning, Unesco. ISBN: 9781894975414

http://hdl.handle.net/11599/36

Butcher, Neil; Hoosen, Sarah (2012). Exploring the business case for open educational resources. Vancouver, BC: Commonwealth of Learning. ISBN: 9781894975599

http://oasis.col.org/handle/11599/57

Cai, Yuzhuo (2013). "Graduate employability: a conceptual framework for understanding employers' perceptions". Higher education, v. 65, n. 4, pp. 457-469.

https://doi.org/10.1007/s10734-012-9556-x

Centra, John A. (2003). "Will teachers receive higher student evaluations by giving higher grades and less course work?". Research in higher education, v. 44, n. 5, pp. 495-518.

https://doi.org/10.1023/A:1025492407752

Clayson, Dennis E. (2009). "Student evaluations of teaching: are they related to what students learn? A meta-analysis and review of the literature". Journal of marketing education, v. 31, n. 1, pp. 16-30.

https://doi.org/10.1177/0273475308324086

Dawe, Lydia; Robinson, Ainslie (2017). "Wikipedia editing and information literacy: a case study". Information and learning science, v. 118, n. 1-2, pp. 5-16.

https://doi.org/10.1108/ILS-09-2016-0067

De-Freitas, Sara-Isabella; Morgan, John; Gibson, David (2015). "Will MOOCs transform learning and teaching in higher education? Engagement and course retention in online learning provision". British journal of educational technology, v. 46, n. 3, pp. 455-471.

https://doi.org/10.1111/bjet.12268 
Denson, Nida; Loveday, Thomas; Dalton, Helen (2010). "Student evaluation of courses: what predicts satisfaction?". Higher education research and development, v. 29, n. 4, pp. 339-356.

https://doi.org/10.1080/07294360903394466

Di-Lauro, Frances; Johinke, Rebecca (2017). “Employing Wikipedia for good not evil: innovative approaches to collaborative writing assessment". Assessment and evaluation in higher education, v. 42, n. 3, pp. 478-491.

https://doi.org/10.1080/02602938.2015.1127322

Doña-Toledo, Luis; Luque-Martínez, Teodoro; Del-Barrio-García, Salvador (2017). “Antecedents and consequences of university perceived value, according to graduates: the moderating role of higher education involvement". International review on public and nonprofit marketing, v. 14, n. 4, pp. 535-565.

https://doi.org/10.1007/s12208-017-0186-y

Dužević, Ines; Mikulić, Josip; Baković, Tomislav (2016). "An extended framework for analysing higher education performance". Total quality management and business excellence, v. 29, n. 5-6, pp. 599-617.

https://doi.org/10.1080/14783363.2016.1224083

Eijkman, Henk (2010). "Academics and Wikipedia: reframing web 2.0+ as a disruptor of traditional academic power-knowledge arrangements". Campus-wide information systems, v. 27, n. 3, pp. 173-185.

https://doi.org/10.1108/10650741011054474

Farmer, Lesley S. J. (2019). "Beyond textbooks: sources of good virtual training”. In: Keengwe, Jared (ed.). Handbook of research on virtual training and mentoring of online instructors. IGI Global, pp. 182-200. ISBN: 9781522563235 https://doi.org/10.4018/978-1-5225-6322-8.ch009

Flanagin, Andrew J.; Metzger, Miriam J. (2011). "From Encyclopædia Britannica to Wikipedia: generational differences in the perceived credibility of online encyclopedia information". Information communication and society, v. 14, n. 3, pp. 355-374.

https://doi.org/10.1080/1369118X.2010.542823

Goldman, Susan R.; Braasch, Jason L. G.; Wiley, Jennifer; Graesser, Arthur C.; Brodowinska, Kamila (2012). "Comprehending and learning from internet sources: processing patterns of better and poorer learners". Reading research quarterly, v. 47, n. 4, pp. 356-381.

http://www.projectreadi.org/wp-content/uploads/2014/10/GoldmanBraaschRRQ2012.pdf

Grewe, Kim E.; Davis, W. Preston (2017). "The impact of enrollment in an OER course on student learning outcomes". International review of research in open and distributed learning, v. 18, n. 4, pp. 231-238.

https://doi.org/10.19173/irrodl.v18i4.2986

Guilbault, Melodi (2018). "Students as customers in higher education: the (controversial) debate needs to end". Journal of retailing and consumer services, v. 40, pp. 295-298.

https://doi.org/10.1016/j.jretconser.2017.03.006

Hadjerrouit, Said (2014). "Wiki as a collaborative writing tool in teacher education: evaluation and suggestions for effective use". Computers in human behavior, v. 32, pp. 301-312.

https://doi.org/10.1016/j.chb.2013.07.004

Hair Jr, Joseph F.; Black, William C.; Babin, Barry J.; Anderson, Rolph E. (2010). Multivariate data analysis. Upper Saddle River, NJ: Prentice Hall. ISBN: 9780138132637

Halavais, Alexander; Lackaff, Derek (2008). "An analysis of topical coverage of Wikipedia”. Journal of computer-mediated communication, v. 13, n. 2, pp. 429-440.

https://doi.org/10.1111/j.1083-6101.2008.00403.x

Hazelkorn, Ellen (2015). Rankings and the reshaping of higher education: the battle for world-class excellence. London: Palgrave Macmillan UK. ISBN: 9781137446671

https://doi.org/10.1057/9781137446671

Hilton III, John (2016). "Open educational resources and college textbook choices: a review of research on efficacy and perceptions". Educational technology research and development, v. 64, n. 4, pp. 573-590.

https://doi.org/10.1007/s11423-016-9434-9

Hsu, Sheng-Hsun; Wang, Yu-Che; Cheng, Chao-Jih; Chen, Yu-Fan (2016). “Developing a decomposed alumni satisfaction model for higher education institutions". Total quality management and business excellence, v. 27, n. 9-10, pp. 979-996. https://doi.org/10.1080/14783363.2015.1054102

Jiménez-Pelayo, Jesús (2009). "Wikipedia como vocabulario controlado: ¿está superado el control de autoridades tradicional?". El profesional de la informacion, v. 18, n. 2, pp. 188-201.

https://doi.org/10.3145/epi.2009.mar.09 
Kahu, Ella R.; Nelson, Karen (2018). "Student engagement in the educational interface: understanding the mechanisms of student success". Higher education research \& development, v. 37, n. 1, pp. 58-71.

https://doi.org/10.1080/07294360.2017.1344197

Kember, David; Leung, Doris Y. P. (2011). "Disciplinary differences in student ratings of teaching quality". Research in higher education, v. 52, n. 3, pp. 278-299.

https://doi.org/10.1007/s11162-010-9194-z

Kennedy, Ryan; Forbush, Eric; Keegan, Brian; Lazer, David (2015). "Turning introductory comparative politics and elections courses into social science research communities using Wikipedia: improving both teaching and research". Political science \& politics, v. 48, n. 2, pp. 378-384.

https://doi.org/10.1017/S1049096514002157

Kim, Kyung-Sun; Sin, Sei-Ching-Joanna; Tsai, Tien I. (2014). "Individual differences in social media use for information seeking". The journal of academic librarianship, v. 40, n. 2, pp. 171-178.

https://doi.org/10.1016/j.acalib.2014.03.001

Kim, Young K.; Sax, Linda J. (2014). "The effects of student-faculty interaction on academic self-concept: does academic major matter?". Research in higher education, v. 55, n. 8, pp. 780-809.

https://doi.org/10.1007/s11162-014-9335-x

Knight, Charles; Pryke, Sam (2012). "Wikipedia and the university, a case study". Teaching in higher education, v. 17, n. 6, pp. 649-659.

https://doi.org/10.1080/13562517.2012.666734

Konieczny, Piotr (2014). "Rethinking Wikipedia for the classroom”. Contexts, v. 13, n. 1, pp. 80-83. https://doi.org/10.1177/1536504214522017

Konieczny, Piotr (2016). "Teaching with Wikipedia in a $21^{\text {st }}$-century classroom: perceptions of Wikipedia and its educational benefits". Journal of the Association for Information Science and Technology, v. 67, n. 7, pp. 1523-1534. https://doi.org/10.1002/asi.23616

Lam, Shun-Yin; Shankar, Venkatesh; Erramilli, M. Krishna; Murthy, Bvsan (2004). "Customer value, satisfaction, loyalty, and switching costs: an illustration from a business-to-business service context". Journal of the Academy of Marketing Science, v. 32, n. 3, pp. 293-311. https://doi.org/10.1177/0092070304263330

Lee, Hyuck-Gi; Chung, Sungwon; Lee, Won-Hee (2012). "Presence in virtual golf simulators: the effects of presence on perceived enjoyment, perceived value, and behavioral intention". New media \& society, v. 15, n. 6, pp. 930-946. https://doi.org/10.1177/1461444812464033

Lerga, Maura; Aibar, Eduard (2015). Best practice guide to use Wikipedia in university education. Recursos de Aprendizaje UOC. Barcelona: Universitat Oberta de Catalunya. http://openaccess.uoc.edu/webapps/o2/handle/10609/41662

Lim, Sook (2009). "How and why do college students use Wikipedia?". Journal of the American Society for Information Science and Technology, v. 60, n. 11, pp. 2189-2202.

https://doi.org/10.1002/asi.21142

Lladós-Masllorens, Josep; Aibar, Eduard; Meseguer-Artola, Antoni; Minguillón, Julià; Lerga, Maura (2017). “Explaining teaching uses of Wikipedia through faculty personal and contextual features". Online information review, v. 41, n. 5, pp. 728-743.

https://doi.org/10.1108/OIR-10-2016-0298

Longva, Kjersti-Kjos; Foss, Lene (2018). “Measuring impact through experimental design in entrepreneurship education: a literature review and research agenda". Industry and higher education, v. 32, n. 6, pp. 358-374. https://doi.org/10.1177/0950422218804912

Luque-Martínez, Teodoro; Doña-Toledo, Luis (2019). "Yes, I can (get satisfaction): an artificial neuronal network analysis of satisfaction with a university". Studies in higher education, v. 44, n. 12, pp. 2249-2264. https://doi.org/10.1080/03075079.2018.1483911

Madden, Andrew D.; Ford, Nigel; Gorrell, Genevieve; Eaglestone, Barry; Holdridge, Peter (2012). “Metacognition and web credibility". The electronic library, v. 30, n. 5, pp. 671-689.

https://doi.org/10.1108/02640471211275710

Meseguer-Artola, Antoni (2014). "Aprenent mitjançant la comparació amb la Wikipedia: la seva importància en l'aprenentatge dels estudiants". RUSC. Universities and knowledge society journal, v. 11, n. 2, pp. 55-65.

https://doi.org/10.7238/rusc.v11i2.2042 
Meseguer-Artola, Antoni; Aibar, Eduard; Lladós, Josep; Minguillón, Julià; Lerga, Maura (2016). “Factors that influence the teaching use of Wikipedia in higher education". Journal of the Association for Information Science and Technology, v. 67, n. 5 , pp. $1224-1232$.

https://doi.org/10.1002/asi.23488

Mesgari, Mostafa; Okoli, Chitu; Mehdi, Mohamad; Nielsen, Finn-Årup; Lanamäki, Arto (2015). "'The sum of all human knowledge': a systematic review of scholarly research on the content of Wikipedia". Journal of the Association for Information Science and Technology, v. 66, n. 2, pp. 219-245.

https://doi.org/10.1002/asi.23172

Minguillón, Julià; Lerga, Maura; Aibar, Eduard; Lladós-Masllorens, Josep; Meseguer-Artola, Antoni (2017). “Semi-automatic generation of a corpus of Wikipedia articles on science and technology". El profesional de la informacion, v. 26, n. 5, pp. 995-1004.

https://doi.org/10.3145/epi.2017.sep.20

Okoli, Chitu; Mehdi, Mohamad; Mesgari, Mostafa; Nielsen, Finn-Årup; Lanamäki, Arto (2014). "Wikipedia in the eyes of its beholders: a systematic review of scholarly research on Wikipedia readers and readership". Journal of the Association for Information Science and Technology, v. 65, n. 12, pp. 2381-2403.

https://doi.org/10.1002/asi.23162

Palmer, Rosemary G.; Stewart, Roger A. (1997). "Nonfiction trade books in content area instruction: realities and potential". Journal of adolescent \& adult literacy, v. 40, n. 8, pp. 630-641.

https://www.jstor.org/stable/40013474

Park, Taemin-Kim (2011). "The visibility of Wikipedia in scholarly publications". First Monday, v. 16, n. 8. https://doi.org/10.5210/fm.v16i8.3492

Picton, Catherine; Kahu, Ella R.; Nelson, Karen (2018). “'Hardworking, determined and happy': first-year students' understanding and experience of success". Higher education research \& development, v. 37, n. 6, pp. 1260-1273. https://doi.org/10.1080/07294360.2018.1478803

Pifarré, Manoli; Li, Li (2018). "Characterizing and unpacking learning to learn together skills in a wiki project in primary education". Thinking skills and creativity, v. 29, pp. 45-58.

https://doi.org/10.1016/j.tsc.2018.06.004

Pike, Gary R. (1999). "The constant error of the halo in educational outcomes research". Research in higher education, v. 40, n. 1 , pp. $61-86$.

https://doi.org/10.1023/A:1018774311468

Pinto, Luisa H.; Ramalheira, Diogo C. (2017). "Perceived employability of business graduates: the effect of academic performance and extracurricular activities". Journal of vocational behavior, v. 99, pp. 165-178.

https://doi.org/10.1016/j.jvb.2017.01.005

Podsakoff, Philip M.; MacKenzie, Scott B.; Podsakoff, Nathan P. (2012). "Sources of method bias in social science research and recommendations on how to control it". Annual review of psychology, v. 63, n. 1, pp. 539-569.

https://doi.org/10.1146/annurev-psych-120710-100452

Praslova, Ludmila (2010). "Adaptation of Kirkpatrick's four level model of training criteria to assessment of learning outcomes and program evaluation in higher education". Educational assessment, evaluation and accountability, v. 22, n. 3, pp. 215-225.

https://doi.org/10.1007/s11092-010-9098-7

Rasmussen, Ingvill; Damşa, Crina I. (2017). "Heterochrony through moment-to-moment interaction: a micro-analytical exploration of learning as sense making with multiple resources". International journal of educational research, v. 84, pp. 79-89.

https://doi.org/10.1016/j.ijer.2016.04.003

Ricaurte-Quijano, Paola; Carli-Álvarez, Arianna (2016). “The wiki learning project: Wikipedia as an open learning environment". Comunicar, v. 24, n. 49, pp. 61-69.

https://doi.org/10.3916/C49-2016-06

Richter, Tobias; Maier, Johanna (2017). “Comprehension of multiple documents with conflicting information: a two-step model of validation". Educational psychologist, v. 52, n. 3, pp. 148-166.

https://doi.org/10.1080/00461520.2017.1322968

Rodríguez-Ardura, Inma; Meseguer-Artola, Antoni (2016). "What leads people to keep on e-learning? An empirical analysis of users' experiences and their effects on continuance intention". Interactive learning environments, v. 24, n. 6 , pp. 1030-1053.

https://doi.org/10.1080/10494820.2014.926275 
Rodríguez-Ardura, Inma; Meseguer-Artola, Antoni (2017). "Flow in e-learning: what drives it and why it matters". British journal of educational technology, v. 48, n. 4, pp. 899-915. https://doi.org/10.1111/bjet.12480

Rouet, Jean-François (2012). The skills of document use: from text comprehension to web-based learning. New York, NY: Routledge. ISBN: 9780415654548

Saichaie, Kem; Morphew, Christopher C. (2014). "What college and university websites reveal about the purposes of higher education". The journal of higher education, v. 85, n. 4, pp. 499-530.

https://doi.org/10.1353/jhe.2014.0024

Saorín, Tomás; Pastor-Sánchez, Juan-Antonio (2011). "Bancos de imágenes para proyectos enciclopédicos: el caso de Wikimedia Commons". El profesional de la informacion, v. 20, n. 4, pp. 424-431.

https://doi.org/10.3145/epi.2011.jul.09

Schüler, Anne (2019). "The integration of information in a digital, multi-modal learning environment". Learning and instruction, v. 59, pp. 76-87.

https://doi.org/10.1016/J.LEARNINSTRUC.2017.12.005

Selwyn, Neil; Gorard, Stephen (2016). "Students' use of Wikipedia as an academic resource - Patterns of use and perceptions of usefulness". Internet and higher education, v. 28, pp. 28-34.

https://doi.org/10.1016/j.iheduc.2015.08.004

Shen, Xiao-Liang; Cheung, Christy M. K.; Lee, Matthew K. O. (2013). "What leads students to adopt information from Wikipedia? An empirical investigation into the role of trust and information usefulness". British journal of educational technology, v. 44, n. 3, pp. 502-517.

https://doi.org/10.1111/j.1467-8535.2012.01335.x

Sigalov, Shani-Evenstein; Nachmias, Rafi (2017). "Wikipedia as a platform for impactful learning: a new course model in higher education". Education and information technologies, v. 22, n. 6, pp. 2959-2979.

https://doi.org/10.1007/s10639-016-9564-z

Sin, Sei-Ching-Joanna (2016). "Social media and problematic everyday life information-seeking outcomes: differences across use frequency, gender, and problem-solving styles". Journal of the Association for Information Science and Technology, v. 67, n. 8, pp. 1793-1807.

https://doi.org/10.1002/asi.23509

Soler-Adillon, Joan; Pavlovic, Dragana; Freixa, Pere (2018). "Wikipedia en la universidad: cambios en la percepción de valor con la creación de contenidos". Comunicar, v. 26, n. 54, pp. 39-48.

https://doi.org/10.3916/C54-2018-04

Strahan, Sarah; Credé, Marcus (2015). "Satisfaction with college: re-examining its structure and its relationships with the intent to remain in college and academic performance". Journal of college student retention: Research, theory and practice, v. 16, n. 4 , pp. 537-561.

https://doi.org/10.2190/CS.16.4.d

Strømsø, Helge I.; Bråten, Ivar; Samuelstuen, Marit S. (2003). "Students' strategic use of multiple sources during expository text reading: a longitudinal think-aloud study". Cognition and instruction, v. 21, n. 2, pp. 113-147.

https://doi.org/10.1207/S1532690XCl2102 01

Sussman, Stephanie-Watts; Siegal, Wendy-Schneier (2003). "Informational influence in organizations: an integrated approach to knowledge adoption". Information systems research, v. 14, n. 1, pp. 47-65.

https://doi.org/10.1287/isre.14.1.47.14767

Tam, Maureen (2014). "Outcomes-based approach to quality assessment and curriculum improvement in higher education". Quality assurance in education, v. 22, n. 2, pp. 158-168.

https://doi.org/10.1108/QAE-09-2011-0059

Thornton, Barry; Adams, Michael; Sepehri, Mohamad (2016). "The impact of students expectations of grades and perceptions of course difficulty, workload, and pace on faculty evaluations". Contemporary issues in education research, v. 3, n. 12, pp. 1-6.

https://doi.org/10.19030/cier.v3i12.917

Tohidinasab, Fariba; Jamali, Hamid R. (2016). "Why and where Wikipedia is cited in journal articles?" Journal of scientometric research, v. 2, n. 3, p. 231.

https://doi.org/10.4103/2320-0057.135415

Tomaszewski, Robert; MacDonald, Karen I. (2016). "A study of citations to Wikipedia in scholarly publications". Science and technology libraries, v. 35, n. 3, pp. 246-261.

https://doi.org/10.1080/0194262X.2016.1206052 
Umbach, Paul D.; Porter, Stephen R. (2002). "How do academic departments impact student satisfaction? Understanding the contextual effects of departments". Research in higher education, v. 43, n. 2, pp. 209-234.

https://doi.org/10.1023/A:1014471708162

Walker, Martin A.; Li, Ye (2016). "Improving information literacy skills through learning to use and edit Wikipedia: a chemistry perspective". Journal of chemical education, v. 93, n. 2, pp. 509-515.

https://doi.org/10.1021/acs.jchemed.5b00525

Wilkins, Stephen; Butt, Muhammad-Mohsin; Kratochvil, Daniel; Balakrishnan, Melodena-Stephens (2016). "The effects of social identification and organizational identification on student commitment, achievement and satisfaction in higher education". Studies in higher education, v. 41, n. 12, pp. 2232-2252.

https://doi.org/10.1080/03075079.2015.1034258

Wineburg, Samuel S. (1991). "Historical problem solving: a study of the cognitive processes used in the evaluation of documentary and pictorial evidence". Journal of educational psychology, v. 83, n. 1, pp. 73-87.

https://doi.org/10.1037/0022-0663.83.1.73

Winkel, Wilco-Te; Rikers, Remy; Loyens, Sofie; Schmidt, Henk (2006). "Influence of learning resources on study time and achievement scores in a problem-based curriculum". Advances in health sciences education, v. 11, n. 4, pp. $381-389$. https://doi.org/10.1007/s10459-006-9016-4

York, Travis T.; Gibson, Charles; Rankin, Susan (2015). "Defining and measuring academic success". Practical assessment, research \& evaluation, v. 20, art. 5.

https://scholarworks.umass.edu/cgi/viewcontent.cgi?article=1260\&context=pare

Zhang, Xiaodong (2018). "Connecting OER with mandatory textbooks in an EFL classroom: a language theory-based material adoption". International review of research in open and distributed learning, v. 19, n. 2.

https://doi.org/10.19173/irrodl.v19i2.3479

Zucker, Benjamin E.; Kontovounisios, Christos (2018). "It is time to improve the quality of medical information distributed to students across social media". Advances in medical education and practice, v. 9, pp. 203-205.

https://doi.org/10.2147/AMEP.S155398

\begin{tabular}{|l} 
Libros científicos de Información, Documentación y Comunicación \\
Documentación musical \\
de Cristina Martí-Martínez
\end{tabular}

